\title{
Challenges Encounter on Teachers' Practice of Using Literary Texts to Teach Reading Skills: Some Selected High Schools in Enbse Sar Mider Woreda
}

\author{
Dawit Dibekulu Alem \\ Lecturer at Mekdela Amba University, College of Social Sciences and Humanities, Department of English \\ Language and Literature, Ethiopia
}

\begin{abstract}
This study aimed to assess challenges encounter the teachers' practice of using literary texts to teach reading skills: in case of Abreha Woatsebeha, Alusha, Segno Gebya,and Debo Secondary school. For this, descriptive survey design and both quantitative and qualitative data analyses approaches were employed. The samples were 38 teachers selected using comprehensive sampling. Questionnaire and semi structured interview were data collection tools. Descriptive statistics (frequency and percentage) was used to analyze the quantitative data and thematic narration for qualitative. The findings of the study revealed teachers' practices of teaching reading skill through literary texts faced challenged by a number of factors. Of which teachers' and students' attitude toward literary texts, lack of experience and preparation, text authenticity, difficulty, length, and large class size, students' motivation, and perception, shortage of time, lack of literary texts in the school, lack of in-service training and supervision are found the major ones. Finally, to meet the needs and interest of the teachers' and students', English language curriculum, syllabus designers, should consider their cultural background, linguistic level, and communicative competences.
\end{abstract}

Keywords: literature, text, practice, challenges, Reading Skill

DOI: $10.7176 /$ JLLL/70-04

Publication date:July $31^{\text {st }} 2020$

\section{Introduction}

Literary materials in the classroom can create an exposure for students to practice extensive and intensive reading. Furthermore, it is proved that incorporating literary materials in reading lesson can help students to master literal understanding of the characters, setting, and them; in comprehending these, students are motivated to work collaboratively and promote problem-solving abilities Mohammad(2011) as cited in Murat(2005). Due to various roles and contribution of literately materials for language teaching purppose. Literary texts were initially the main source of input for teaching in language classes in the era of Grammar Translation Method but since then it has been dropped down the pedestal. In fact with the advent of structuralism and audio-lingual method, literature was downplayed and ergo discarded to the periphery (Collie \& Slater, 1987, p.2). Also in the era of CLT, literature was neglected and more attention was given to dialogues and conversations which were more practical and visible in the real world situation.

Due to various roles and contribution of literately materials for language teaching purpose, learner motivation, authenticity of subject matter, cultural/ intercultural awareness and globalization, intensive as well as extensive reading practice, grammar and vocabulary knowledge are some of the possible results in the use of works of literature in language teaching. Theoretically, using of literature in language teaching is very advantageous that it offers four benefits: authentic material, cultural enrichment, language advancement, and personal growth (Collie \& Slater, 1991). This is in line with Erkaya (2005) who notes four benefits of using short stories to teach ESL/EFL, i.e. motivational, literary, cultural and higher-order thinking benefits. Scholars such as Lazar (1993, p, 15) strongly agree on the use of literature to teach language. Hence, there were scholars who believe that literature can be a valuable asset in language class. She stressed that literature motivates students, encourage them to learn the language, express their feelings, help them to develop their language comprehension, help them to relax etc.

Reading is one of the effective means of extending the command of language. It has considerable place in language learning programs. It determines learners' success in academic studies and personal development. It also enhances learners' language proficiency. Nuttall (1996) states that, reading if implemented effectively, can lend itself to the development of other language skills. Most importantly, in educational setting where a foreign language serves as a medium of instruction at high school level, as in the case of Ethiopia, the role of reading skill is significant in the students' academic career. Furthermore, Nuttal (1982) and Wallace (1992) argue that reading can mean the ability to understand or interpret a text.

Due to various roles and contribution of literately materials for language teaching purposes, Yenialem (2014) admitted that literary texts are now part of the Ethiopian English language curriculum and syllabus. For these reason, among various authentic materials used for language teaching purpose, literary texts like short stories, poems, and biographies have been using as a fundamental and decisive inputs incorporated in Ethiopian grade 
nine, ten, eleven and twelve students' textbook. Accordingly, a number of scholars and researchers argue that in reading literary texts, students can develop the exposure to learn and practice various communicative and linguistic competencies (Murat2005).On the other hand, Haileleul (2012) confirmed that in Ethiopian context, teaching literary reading texts in English language classroom has found vital and serves as a means for students' language advancement and inter cultural competences, provision of linguistic and cross cultural explanation and development of feeling for language learning.

Moreover, Özkan \& Nejat (2014) studied on use of literature in reading comprehension classes by elt teachers. The findings reveal that in general ELT teachers use literature in their reading classes; however, they consider restrictions of the curriculum, insufficient class time, and crowded classes as hindrances. They also added that, their perception of literary works to be linguistically difficult, demotivating, and their reliance on teachers to paraphrase, clarify, interpret, and explain appears as other significant reasons for using little or no literature for reading comprehension activities.

Different local study have been conducted related to these area for example, Yitagesu (2017) indicates that the literary texts enhanced the students' reading comprehension. Ketema (2012) found that it was difficult to generalize the teachers and the students' views towards literary texts and its uses in the English language classrooms. In principle, most teachers and students perceive literary texts as useful in terms of language development. However, they lacked the knowledge to integrate the literary texts with the teaching of language skills effectively. Furthermore, Kefyalewet.al.,(2013) indicates that literary texts in teaching reading skill provides opportunities for them to develop literal understanding, and promote problem-solving ability. For this reason, Ministry of Education in Ethiopia launched to incorporate literary texts in EFL students' textbook. However, it was not yet implemented effectively.

But the difference and the gap that is needed to fill by the current research would be the first thing this research would see as can be suggested by different researcher there is a gap in the practice of teaching in language classroom especial the teacher failed to teach English language skills by using literary texts. And in the current study area as far as the research reading concerned there is no study conducted in the same issue with the current study. So, the issue and context as well as the population were considered as one gap. In addition to, the researcher himself was learned one of the selected school and has an experiences revealed to observe the schools and discussed with the teacher in these schools so, from his experience and the discusses the researcher understand that the teachers were not used literary text in teaching language as well as reading skills as per the text book includes different literary text in it. So, these things motivated the researcher to conduct a study on the challenges which encounter the practice of teachers in using literary texts to teach reading skills. To this end, this study aimed to assess the challenges encounter on the teachers' practice of using literary texts to teach reading skills.

So, to achieve this objective the current study raised following research questions:

1. What are the challenges that the teachers encounter when they teaching reading through literary texts?

2. What are the dominant factors which hinders the teachers that the teachers encounter when they teaching reading through literary texts (among the identified factors)?

\section{Research Methodology}

\subsection{Research Design}

Descriptive survey design and mixed data analysis approaches were employed in this study. According to Kothari (2004), descriptive survey research studies are concerned with describing the characteristics of a particular individual, or of a group. Similarly, As Creswell (2014) explained survey design provides a quantitative or numeric description of trends, attitudes, or opinions of a population by studying a sample of that population. As the nature of the study was describing the challenges which encounter the practice of teacher teachers' in teaching reading through literary texts descriptive survey design is felt to be appropriate.

\subsection{Population, Sample, and Sampling Technique 2.2.1 Population of the study}

The target population consisted of the teachers of English in Abreha Woatsebha, Alusha and Segno Gebya and Debo secondary school. The study will be conducted by taking three of these schools taking grade $9^{\text {th }}$ English language teachers into consideration. Thus the population of the study was teachers (179), students (1645) and administrative bodies in these three schools. The target populations were all English language teachers (38). Administrative bodies and other grade levels are neglected intentionally.

\subsubsection{Sample and Sampling Technique}

Regarding to the research, the schools were selected purposively since these three schools are closer to the researcher and he was learned in one of the schools. So, it will help the researcher to get pertinent data. As indicated in the table below the samples was taken from each of the schools by using comprehensive sampling. After comprehensive sampling was made all $38(100 \%)$ teachers were selected out of 38 teachers. 
Table 1: Summary of population, sample and sampling Techniques

\begin{tabular}{|c|c|c|c|c|c|c|}
\hline \multirow{3}{*}{ 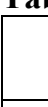 } & \multirow{3}{*}{ School name } & \multirow{3}{*}{\multicolumn{2}{|c|}{ Target population }} & \multirow{2}{*}{\multicolumn{2}{|c|}{ Sample }} & \multirow{3}{*}{ Sampling techniques } \\
\hline & & & & & & \\
\hline & & & & $\mathrm{F}$ & $\%$ & \\
\hline \multirow[t]{3}{*}{1} & \multirow{3}{*}{$\begin{array}{l}\text { Abreha Woatsebha } \\
\text { secondary school }\end{array}$} & $\mathrm{M}$ & 7 & 7 & 100 & \multirow[t]{3}{*}{ comprehensive sampling } \\
\hline & & $\mathrm{Fe}$ & 5 & 5 & 100 & \\
\hline & & $\mathrm{T}$ & 12 & 12 & 100 & \\
\hline \multirow[t]{3}{*}{2} & \multirow{3}{*}{$\begin{array}{l}\text { Alusha Secondary } \\
\text { School }\end{array}$} & $\mathrm{M}$ & 5 & 5 & 100 & \multirow[t]{3}{*}{ comprehensive sampling } \\
\hline & & $\mathrm{Fe}$ & 3 & 3 & 100 & \\
\hline & & $\mathrm{T}$ & 8 & 8 & 100 & \\
\hline \multirow[t]{3}{*}{3} & \multirow{3}{*}{$\begin{array}{l}\text { Segno Gebya } \\
\text { Secondary school }\end{array}$} & $\mathrm{M}$ & 5 & 5 & 100 & \multirow[t]{3}{*}{ comprehensive sampling } \\
\hline & & $\mathrm{Fe}$ & 2 & 2 & 100 & \\
\hline & & $\mathrm{T}$ & 7 & 7 & 100 & \\
\hline \multirow[t]{3}{*}{4} & \multirow{3}{*}{$\begin{array}{ll}\text { Debo } & \text { Secondary } \\
\text { School } & \end{array}$} & $\mathrm{M}$ & 7 & 7 & 100 & \multirow[t]{3}{*}{ comprehensive sampling } \\
\hline & & $\mathrm{Fe}$ & 4 & 4 & 100 & \\
\hline & & $\mathrm{T}$ & 11 & 11 & 100 & \\
\hline 5 & Total number & $\mathrm{T}$ & 38 & 38 & 100 & comprehensive sampling \\
\hline
\end{tabular}

Key: M; male, Fe- female, T-total, F- Frequency

\subsection{Data Collection Instruments}

In order to collect data from the samples of the target population, it was collected using classroom observation, questionnaire, and focus group discussion. All instruments of data collection were designed in a way to measure teachers teaching practice and perception based on selected criteria. All the items were made to be based on literature and theoretical assumptions.

\subsubsection{Questionnaire}

Questionnaires are a good way to obtain information from a large number of people and/or people who may not have the time to attend an interview or take part in experiments. They enable people to take their time, think about it and come back to the questionnaire later (Marshall \& Rossman, 1989). A questionnaire was prepared for teachers which contain relevant points to the study. Different items were developed by the researcher based on theoretical bases of teaching reading by using literary text and by adapting some items from other researchers. In this study it was aimed to identify the factors which affect the practice of teacher in using literary text in teaching reading through literary texts. So, a questionnaire which consists of both closed and one open ended item were design for the sample teachers in this research. All the items of the teachers and students were basically the same in terms of content although some could be worded slightly different.

\subsubsection{Interview}

Interview was one of the instruments for this study. It was conducted with selected teachers. For an interpretive research paradigm, in-depth interview is a primary method of data collection tool (Creswell, 2003). Hence, semi structured interview was employed with five teachers with the purpose to uncover the factors they encounters in teaching reading skill using literary texts in the classroom scenario because it enabled him to investigate relevant data from the respondents by raising different questions accordingly. The interview contained open ended questions which were related to the challenges of using literary text in teaching reading and it was conducted with mother tongue language in order to investigate the data deeply from grade $9^{\text {th }}$ English language teachers. Some factors are mainly covert behaviors that teachers may not certainly respond to that part of the questionnaire. It is believed that, therefore, better evidence could be obtained if teachers' will be invited to tell in a face to face communication. When interview carried out, audio recorder was used to keep all the row data accessible for data interpretation and analyses.

\subsection{Validity and Reliability of the Instruments}

The reliability and validity for the instruments was checked before the instrument distributed and hold on to the respondents.

\subsubsection{Validity of the Instruments}

Before the actual data collection process was made validity was checked (face, content and construct validity) by consulting English language teachers in Debre Markos university (their specialization is TEFL) and tools were revised accordingly (from student questionnaire English version) 6 items were revised and for teachers questionnaires 3 instructions and 7 items were made some modification based on the comments), and 3 items related to strategies were deleted. And the Amharic version also checked by Debre Markos University Amharic language teachers and there are minor modification on some contents ( 5 items).

\subsubsection{Reliability of the Instruments}

After all the instruments was made ready, their reliabilities were check by using pilot test in one of secondary 
schools in Enbse Sar Midr Woreda ( Dembza General Secondary and Preparatory school) and calculating the reliability coefficients using Crombach alpha for factors found that 0.89 respectively which was acceptable. Regarding this, Crombach(1951) forwarded that commonly accepted rule for describing internal consistency using Cranach's alpha is $0.90 \leq \alpha$ is excellent, $0.80 \leq \alpha<0.90$ is good, $0.70 \leq \alpha$ is acceptable $<0.80,0.60 \leq \alpha<0.70$ is questionable , $0.50 \leq \alpha<0.60$ is poor, and $\alpha<0.5$ is unacceptable. So, in regarding to the reading phase the items have good, reading strategies and factors were also acceptable.

\subsection{Data Collection Procedures}

In the first place to get authentic data respondents were volunteer, willing and positive. For this cooperation letter was written from the college, and the researcher explained the purpose of the study by communicating with school directors and teachers. After this happens all the instruments was made ready, proper time for data collection was arranged and problems was handled accordingly. The other thing that the researcher has been done that orientation was given for teachers before they fill and respond for the questions. In addition to this, questionnaire was holding on first, and interview comes second.

\subsection{Data Analysis Technique}

As indicated both qualitative and quantitative techniques were employed to analyze the data collected. The quantitative data was analyzed using descriptive statistics (frequency count, and percentage) was employed. The qualitative data was analyzed using narration.

\section{Analyses and Discussions of Results}

\subsection{Introduction}

This chapter is all about the data collected results and discussion made based on the obtained results. It is organized starting from the demographic data of respondents and continues to the main data analysis collected through questionnaires, focus group discussion, and observation. For the analysis of the questionnaires 38 teachers were included. In addition, interview were conducted on 5 teachers taken from those of the respondents for the questionnaires, are included in this part. So, in this section first the quantitative data which are collected from questionnaire were analyzed by using descriptive statistics and then data collected from observation was analyzed by frequency count and percentage. Then lastly interview was analyzed through nation. Finally, the findings taken from the data were discussed by supporting different empirical and theoretical evidences.

\subsection{Demographic Data Analysis of Respondents}

Teachers were samples of the study. Teacher's sex, educational qualification and experiences are reported as follows.

Table 2: Respondents demographics data

\begin{tabular}{|l|l|l|l|}
\hline \multirow{2}{*}{ Demographic characteristics } & \multicolumn{1}{|c|}{ Description } & \multicolumn{2}{|c|}{ Respondents } \\
\cline { 2 - 4 } & & $\mathrm{N}$ & $\%$ \\
\hline \multirow{5}{*}{ Sex } & Male & 25 & 65.8 \\
\cline { 2 - 4 } & Female & 13 & 34.2 \\
\cline { 2 - 4 } & Total & 38 & 100.00 \\
\hline \multirow{3}{*}{ Educational Qualification } & First Degree & 33 & 86.8 \\
\cline { 2 - 4 } & $2^{\text {nd }}$ Degree & 5 & 13.2 \\
\hline \multirow{5}{*}{ Experiences in years } & $6-10$ years & 18 & 47.4 \\
\cline { 2 - 4 } & $11-15$ years & 3 & 39.5 \\
\cline { 2 - 4 } & $16-20$ years & 2 & 7.9 \\
\cline { 2 - 4 } & Above 20 years & 5.2 \\
\hline
\end{tabular}

As indicated in table two 38 teachers male 25(67.8\%) and female $13(34.2 \%)$ were assigned to teach in high school besides this, 33(86.8\%) and 5(13.2\%) were first degree and second degree holders in that order. In relation to their experiences, $18(47.4 \%), 15(39.5 \%), 3(7.9 \%)$ and $2(5.2 \%)$ were reported as they have $6-10$ years, 11-15 , 16-20 and above 20 years of experiences respectively.

From this, it is possible to infer that the samples included were appropriate to collect pertinent data for the intended purpose.

\subsection{Quantitative Data Analysis}

The quantitative data included teachers' questionnaires that aimed to indicate teachers' perceptions and their actual practices of using literary text in teaching reading. In addition, identify the challenges that defect the implementation of using literary text in teaching reading. The quantitative data was presented with tables that contained the items, frequencies and percent's of responses, numbers of respondents. Furthermore, the grand mean 
score of each table was calculated so as to attempt the analysis clearly.

\subsubsection{Teachers' Questionnaire}

The questionnaire which was administered to teachers and it aimed to answer the expected factors related to students, teachers, subject matter contexts, and contexts are analyzed.

For the aforementioned purposes, a total of 38 teachers participated from those three secondary and preparatory schools of Addis Ababa. To this effect, for EFL teachers 38 copies of questionnaire were distributed among these $38(100 \%)$ of the questionnaire were filled and collected. After the data was obtained from questionnaires of all teachers, the data were analyzed as follows.

\subsubsection{Student related factors}

Regarding student related factors students were asked to respond for 6 items related to students as influencing factors in the process of teaching reading through literary text. Thus based on their responses the following results are obtained and reported as that of teachers.

Table 3. Student related factors that may affect your actual practices in teaching reading skills by using literary text

\begin{tabular}{|c|c|c|c|c|c|c|c|c|c|c|c|c|c|}
\hline \multirow[t]{2}{*}{ No } & \multirow[t]{2}{*}{ Student Related factors } & \multicolumn{2}{|l|}{5} & \multicolumn{2}{|l|}{4} & \multicolumn{2}{|l|}{3} & \multicolumn{2}{|l|}{2} & \multicolumn{2}{|l|}{1} & \multirow[t]{2}{*}{$\mathrm{N}$} & \multirow[t]{2}{*}{ Mean } \\
\hline & & $\mathrm{F}$ & $\%$ & $\mathrm{~F}$ & $\%$ & $\mathrm{~F}$ & $\%$ & $\mathrm{~F}$ & $\%$ & $\mathrm{~F}$ & $\%$ & & \\
\hline 1.1 & Language problem & 30 & 78.9 & 8 & 21.1 & 0 & 0 & 0 & 0 & 0 & 0 & 38 & 4.79 \\
\hline 1.2 & $\begin{array}{l}\text { Being unfamiliar with } \\
\text { literary texts }\end{array}$ & 28 & 73.7 & 10 & 26.3 & 0 & 0 & 0 & 0 & 0 & 0 & 38 & 4.74 \\
\hline 1.3 & $\begin{array}{l}\text { Being unable to } \\
\text { understand every } \text { word } \\
\text { in the text }\end{array}$ & 20 & 52.6 & 10 & 26.3 & 8 & 21 & 0 & 0 & 0 & 0 & 38 & 4.32 \\
\hline 1.4 & $\begin{array}{l}\text { Lack of confidence to do } \\
\text { tasks }\end{array}$ & 5 & 13.2 & 5 & 13.2 & 10 & 26.3 & 10 & 26.3 & 8 & 21 & 38 & 2.71 \\
\hline 1.5 & $\begin{array}{l}\text { Lack of interest and } \\
\text { motivation } \quad \text { reading } \\
\text { literary text }\end{array}$ & 20 & 52.6 & 10 & 26.3 & 8 & 21 & 0 & 0 & 0 & 0 & 38 & 4.32 \\
\hline 1.6 & $\begin{array}{l}\text { Lack of sufficient } \\
\text { background knowledge }\end{array}$ & 10 & 26.3 & 8 & 21 & 0 & 0 & 0 & 0 & 38 & 4.32 & 38 & 3.61 \\
\hline & & & & & & & & & & & Granc & lean & 4.02 \\
\hline
\end{tabular}

Scales $<1.49$ very slightly, 1.5-2.49 slightly , $2.5-3.49=$ moderately $3.5-4.49=$ highly $>4.5=$ extremely

As stated in table 3 revealed that the response of teacher ranked stated student related factor. There were six expected challenges in relation to teachers that assumed to be the means of barrier for using literary text in teaching reading. The grand mean score of the above table 3 is 4.02 which is found between 3.5-4.49 so it inclined to highly. Therefore, language problem, unfamiliar with literary texts, unable to understand every word in the text, lack of confidence to do tasks, lack of interest and motivation reading literary text, lack of sufficient background knowledge highly challenged teachers to not to use literary texts in teaching reading skills.

According to this, student related factors especial their language problem and unfamiliarity with the text and lack of motivation affect the practice of teachers in using literary text in teaching reading.

\subsubsection{Teacher related factors}

Regarding teacher related factors students were asked to respond for 6 items related to teachers as influencing factors in the process of teaching reading through literary text. Thus based on their responses the following results are obtained and reported as that of teachers.

Table 4. Teacher related factors that may affect your actual practices in teaching reading skills by using literary text

\begin{tabular}{|c|c|c|c|c|c|c|c|c|c|c|c|c|c|}
\hline \multirow[t]{2}{*}{ No } & \multirow[t]{2}{*}{ Teacher Related factors } & \multicolumn{2}{|l|}{5} & \multicolumn{2}{|l|}{4} & \multicolumn{2}{|l|}{3} & \multicolumn{2}{|l|}{2} & \multicolumn{2}{|l|}{1} & \multirow[t]{2}{*}{$\mathrm{N}$} & \multirow[t]{2}{*}{ Mean } \\
\hline & & $\mathrm{F}$ & $\%$ & $\mathrm{~F}$ & $\%$ & $\mathrm{~F}$ & $\%$ & $\mathrm{~F}$ & $\%$ & $\mathrm{~F}$ & $\%$ & & \\
\hline 1.1 & Lack of confidence & 30 & 78.9 & 8 & 21.1 & 0 & 0 & 0 & 0 & 0 & 0 & 38 & 2.78 \\
\hline 1.2 & $\begin{array}{l}\text { Lack of motivation in } \\
\text { teaching reading through } \\
\text { literary text }\end{array}$ & 28 & 73.7 & 10 & 26.3 & 0 & 0 & 0 & 0 & 0 & 0 & 38 & 4.36 \\
\hline 1.3 & $\begin{array}{l}\text { Lack of teaching experiences } \\
\text { in teaching reading through } \\
\text { literary text }\end{array}$ & 20 & 52.6 & 10 & 26.3 & 8 & 21 & 0 & 0 & 0 & 0 & 38 & 4.67 \\
\hline 1.4 & $\begin{array}{l}\text { Lack of using proper } \\
\text { teaching strategies for each } \\
\text { literary text }\end{array}$ & 5 & 13.2 & 5 & 13.2 & 10 & 26.3 & 10 & 26.3 & 8 & 21 & 38 & 3.53 \\
\hline
\end{tabular}




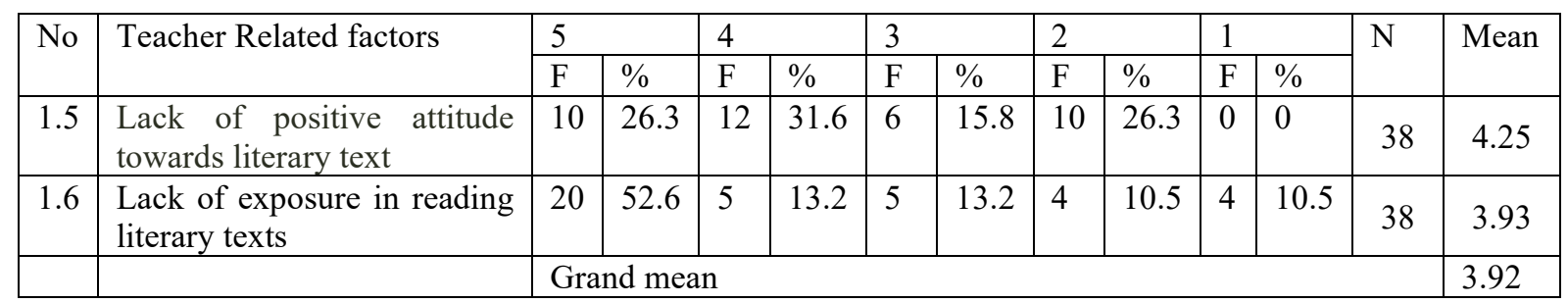

Scales $<1.49$ very slightly, $1.5-2.49$ slightly , $2.5-3.49=$ moderately $3.5-4.49=$ highly $>4.5=$ extremely

Based on the data obtained from Table 4, the grand mean score of the table is 3.92. This shows that the expected challenges in relation to teachers that assumed to be determinant factors that the practice of teachers in using literary text is high since the result indicates usually affect it. Thus absence of self-confidence, motivation in teaching reading by using literary texts, experience teaching in reading through literary text, using proper literary text in teaching reading through literary texts., and exposure in reading literary texts affect the teachers practice of teaching through literary texts.

\subsubsection{Subject matter related factors}

Regarding subject content related factors students were asked to respond for 7 items related to contents of the subject as influencing factors in the process of teaching reading through literary text. Thus based on their responses the following results are obtained and reported as that of teachers.

Table 5. Subject matter related factors that may affect your actual practices in teaching reading skills by using literary text

\begin{tabular}{|c|c|c|c|c|c|c|c|c|c|c|c|c|c|}
\hline \multirow{2}{*}{ No } & \multirow{2}{*}{$\begin{array}{l}\text { Subject matter } \\
\text { related factors }\end{array}$} & \multicolumn{2}{|l|}{5} & \multicolumn{2}{|l|}{4} & \multicolumn{2}{|l|}{3} & \multicolumn{2}{|l|}{2} & \multicolumn{2}{|l|}{1} & \multirow[t]{2}{*}{$\bar{N}$} & \multirow[t]{2}{*}{ Mean } \\
\hline & & $F$ & $\%$ & $F$ & $\%$ & $F$ & $\%$ & $\mathrm{~F}$ & $\%$ & $F$ & $\%$ & & \\
\hline 1.1 & $\begin{array}{l}\text { Difficulty of } \\
\text { vocabulary in the } \\
\text { literary text }\end{array}$ & 0 & 0 & 0 & 0 & 0 & 0 & 30 & 78.9 & 8 & 21.1 & 38 & 1.79 \\
\hline 1.2 & $\begin{array}{l}\text { Unfamiliar literary } \\
\text { text }\end{array}$ & 0 & 0 & 0 & 0 & 0 & 0 & 28 & 73.7 & 10 & 26.3 & 38 & 1.74 \\
\hline 1.3 & $\begin{array}{l}\text { Uninteresting } \\
\text { literary text }\end{array}$ & 0 & 0 & 0 & 0 & 8 & 21 & 20 & 52.6 & 10 & 26.4 & 38 & 1.98 \\
\hline 1.4 & $\begin{array}{l}\text { Lengthy and } \\
\text { detailed literary text }\end{array}$ & 5 & 13.2 & 5 & 13.2 & 10 & 26.3 & 10 & 26.3 & 8 & 21 & 38 & 2.71 \\
\hline 1.5 & $\begin{array}{l}\text { Complicated } \\
\text { grammatical } \\
\text { structure }\end{array}$ & 10 & 26.3 & 12 & 31.6 & 6 & 15.8 & 10 & 26.3 & 0 & 0 & 38 & 3.61 \\
\hline 1.6 & $\begin{array}{l}\text { Lack of sufficient } \\
\text { reading tasks } \\
\text { extracted from the } \\
\text { literary text }\end{array}$ & 20 & 52.6 & 5 & 13.2 & 5 & 13.2 & 4 & 10.5 & 4 & 10.5 & 38 & 3.97 \\
\hline 1.7 & $\begin{array}{l}\text { Lack of varied } \\
\text { literary texts }\end{array}$ & 10 & 26.4 & 4 & 10.5 & 20 & 52.6 & 4 & 10.5 & 0 & 0 & 38 & 2.89 \\
\hline & & & & & & & & & & & & & 2.67 \\
\hline
\end{tabular}

Scales $<1.49$ very slightly, 1.5-2.49 slightly , $2.5-3.49=$ moderately $3.5-4.49=$ highly $>4.5=$ extremely

As stated in table 5 explained that the response of teacher regarding to subject matter related factor. As Table 5 indicated, there were three expected challenges in relation to subject matter that assumed to be hindering factors for the practice of teachers in using literary texts in teaching reading. Thus the grand mean of the above table 5 is 2.67 which is found above 2.5-3.49 and this shows that vocabularies difficulty, the text familiarity level and interestingness, lengthy and detailed literary , complicated grammatical structure, lack of sufficient reading tasks extracted from the literary text, and lack of varied literary texts is placed on moderate level. Form this it is possible to conclude that even though there are some gaps in designing the syllabus the text book tried to advocate the usage of literary text in reading class and it is designed by considering this issue.

\subsubsection{Context related Factors}

Regarding context related factors students were asked to respond for 3 items related to context as influencing factors in the process of teaching reading through literary. Thus based on their responses the following results are obtained and reported as that of teachers. 
Table 6: Context related factors that may affect your actual practices in teaching reading skills by using literary text.

\begin{tabular}{|c|c|c|c|c|c|c|c|c|c|c|c|c|c|}
\hline \multirow[t]{2}{*}{ No } & \multirow[t]{2}{*}{ Context related factors } & \multicolumn{2}{|l|}{5} & \multicolumn{2}{|l|}{4} & \multicolumn{2}{|l|}{3} & \multicolumn{2}{|l|}{2} & \multicolumn{2}{|l|}{1} & \multirow[t]{2}{*}{$\mathrm{N}$} & \multirow[t]{2}{*}{ Mean } \\
\hline & & $\mathrm{F}$ & $\%$ & $\mathrm{~F}$ & $\%$ & $\mathrm{~F}$ & $\%$ & $\mathrm{~F}$ & $\%$ & $\mathrm{~F}$ & $\%$ & & \\
\hline 1.1 & Class room arrangement & 30 & 78.9 & 8 & 21.1 & 0 & 0 & 0 & 0 & 0 & 0 & 38 & 4.65 \\
\hline 1.1 & Large class size & 28 & 73.7 & 10 & 26.3 & 0 & 0 & 0 & 0 & 0 & 0 & 38 & 4.74 \\
\hline 1.2 & $\begin{array}{l}\text { Time constraints to cover the lesson } \\
\text { extracted from each literary text }\end{array}$ & 20 & 52.6 & 18 & 47.4 & 0 & 0 & 0 & 0 & 0 & 0 & 38 & 4.02 \\
\hline & & $\mathrm{Gr}$ & $\mathrm{Me}$ & & & & & & & & & & 4.44 \\
\hline
\end{tabular}

Scales $<1.49=$ never , 1.5-2.49= rarely , $2.5-3.49=$ Sometimes $3.5-4.49=$ usually $>4.5=$ always

As Table 6 indicated, there were three expected challenges in relation to context that assumed to be hindering factors for the practice of teachers in using literary texts in teaching reading. Thus the grand mean of the above table 6 is 4.44 which is found above 4.5 and this shows that classroom arrangement, large class size and time constraints to cover the lesson extracted from each literary text are determined factor for the practice of teachers in using literary text in reading class.

\subsubsection{School related Factors}

Regarding School related factors students were asked to respond for 3 items related to context as influencing factors in the process of teaching reading through literary. Thus based on their responses the following results are obtained and reported as that of teachers.

Table 7: School related factors that may affect your actual practices in teaching reading skills by using literary text.

\begin{tabular}{|c|c|c|c|c|c|c|c|c|c|c|c|c|c|}
\hline \multirow[t]{2}{*}{ No } & \multirow[t]{2}{*}{ School Related Factors } & \multicolumn{2}{|l|}{5} & \multicolumn{2}{|l|}{4} & \multicolumn{2}{|l|}{3} & \multicolumn{2}{|l|}{2} & \multicolumn{2}{|l|}{1} & \multirow[t]{2}{*}{$\mathrm{N}$} & \multirow[t]{2}{*}{ Mean } \\
\hline & & $\mathrm{F}$ & $\%$ & $\mathrm{~F}$ & $\%$ & $\mathrm{~F}$ & $\%$ & $\mathrm{~F}$ & $\%$ & $\mathrm{~F}$ & $\%$ & & \\
\hline 1.1 & $\begin{array}{l}\text { Shortage of literary materials that } \\
\text { enable to teach reading }\end{array}$ & 30 & 78.9 & 8 & 21.1 & 0 & 0 & 0 & 0 & 0 & 0 & 38 & 4.79 \\
\hline 1.2 & Time constraints for preparation & 28 & 73.7 & 10 & 26.3 & 0 & 0 & 0 & 0 & 0 & 0 & 38 & 4.74 \\
\hline 1.3 & $\begin{array}{l}\text { The assessment methods of national } \\
\text { exams }\end{array}$ & 20 & 52.6 & 18 & 47.4 & 0 & 0 & 0 & 0 & 0 & 0 & 38 & 4.53 \\
\hline 1.4 & Lack of classroom supervision & 10 & 26.3 & 28 & 73.7 & 0 & 0 & 0 & 0 & 0 & 0 & 38 & 4.74 \\
\hline 1.5 & $\begin{array}{l}\text { Lack of update training on the current } \\
\text { syllabus }\end{array}$ & 20 & 52.6 & 18 & 47.4 & 0 & 0 & 0 & 0 & 0 & 0 & 38 & 4.53 \\
\hline
\end{tabular}

Scales $<1.49=$ very slightly, $1.5-2.49=$ slightly, $2.5-3.49=$ moderately $3.5-4.49=$ highly $>4.5=$ extremely

As Table 7 indicated, there were three expected challenges in relation to school that assumed to be hindering factors for the practice of teacher in using literary text to teach reading skills. Thus the grand mean of the above table 7 is 4.69 which is found above 4.5 and this shows that 5hortage of literary materials that enable to teach reading, time constraints for preparation, the assessment methods of national exams, lack of classroom supervision, and lack of update training on the current syllabus

\subsection{Qualitative data analysis}

\subsubsection{Open Ended questionnaire data analyses}

Regarding factors that affect the practice of teachers in teaching reading by using literary texts teachers were asked to add additional information which was not mentioned in close ended questionnaire part. So, teachers were responded that the lack background knowledge, poor language proficiency, lack of awareness towards learning the subject, poor design subject content to teach reading comprehension and related strategies, and there is some sort of repetition that makes the students bored to engage them in them in activities. They also stated that the time given to complete the tasks specially the time allowed to teach reading passages by applying reading phases and strategies was not enough and the class sizes were not manageable to engage all the students in each tasks. They also added that the school administrations were not prepares training on the current syllabus and methods to update the pedagogical skills of the teachers.

Thus, this indicates that the factors which are related to students, teachers, content ,context, school are affect the teachers' practice of teaching reading comprehension.

\section{4.2. Interview data Analyses}

Interviewees were also asked what factors influence to teach reading skills by using literary texts. In this regard similar responses were obtained and one of the interviewee responses is reported as follows (coded as T1).

"Using literary texts in teaching reading skills is influenced by a number of factors. The big problem is related to students. Students are not well prepared, motivated, and willing to attend their class actively and they are not interested to engage themselves in such literary text. Another problem is related to text book. The text book is also 
big and huge page to cover all the contents on time as a result I obliged to be fast rather than teaching each of the contents. In addition, there are a lot of interruption times because of different reasons which hamper the teaching and learning process. These push me not to teach all the literary text in reading class. Personally, I feel some teachers are not capable enough to teach as needed."

Form this we can understand that even though the teacher perceived literary texts are essential in teaching reading they were not use frequently due to the language problems, experience of using literary text and syllabus problems.

Teacher 2 (coded as T2) claimed that:

"Well, I face many problems while I am teaching reading through literary texts. To begin with, students do not actively participate in reading passage especial literary passages and do not have interest to do reading literary texts. After they read the text, it is expected that they work in pairs, or in groups to share their knowledge and experience, but they lack willingness to practice the task. They simply follow their teacher as if he read the text word by word and give them feedback for all the activities at hand. Consequently, they prefer to read loudly instead of silent reading. Only a few students have willingness to accomplish the task that their teacher assigned them to do. Secondly, most of the students claimed there are excessive numbers of unfamiliar words in the text, and most of the reading texts are far from students' background knowledge. Thus, they cannot guess the meanings of these new words. They always ask me to translate to their mother-tongue. This implies that students have poor background. These adversely affect students' reading competence and lead them unable use their background knowledge to comprehend the text/ the message that the author what intended to convey as effectively as possible"

From this it is possible to conclude that problems related to teachers like their background knowledge, willingness to read literary text and language competence problems are the major determinant for the practice of teacher in teaching reading by using literary text.

Teacher 3 coded as T3 expressed that

"While I am teaching reading by using literary text, I faced different problems. Number one problem was most of my students are less participant in the reading comprehension activities. So whenever I teach reading comprehension, my students are less interested and fewer participants because of lack of experiences and these matters affect students' reading comprehension, and even affect myself i.e., my teaching reading comprehension. Another problem is students' lack of vocabulary knowledge. Still another challenge may be students lack reading habit. The major problem, as I consider it, is the shortage of reading materials. And also we teacher are not capable enough to teach literary texts."

This indicates that students capacity material problem and teacher also the factor for teaching reading through literary text.

Teacher 4 coded as T4 explained that:

"What I face during teaching of reading through literary texts, they were not ready to learn and again their competency to this level is very low. Still the other problem is the way how the teachers teach reading by using literary text is also another problem: Teacher-wise, or teacher-centred. There is also class-wise problem for example if a teacher jumps a text which students are supposed to read, they may lose interest. In other words, the focus of the teacher can adversely affect the interest of the students to be low. Besides, the contents of the text itself are another factor as they are too immense to cover within the allotted time and do not advocate variety of literary text in it. This creates tension for the teacher so that the teacher sometimes forced to skip over some reading texts due to shortage of time. In addition to this, the background knowledge of the students, I think, is under a problem or poor. They are not built on reading comprehension through their learning. This is to mean, reading comprehension is not focused by students. So, here and there, there are problems in relation to students' interest and their background knowledge. These are the main problem which I face when I teach reading comprehension." Teacher 5 coded as $\mathrm{T} 5$ explained that:

"Yeah! As an English teacher I tried my best to use to teach reading skills by using literary text problem. For example, I tried to initiate my students for learning reading through literary texts. This is because literary texts are valuable to reading skills. Our students must not only be grammatical learners, but also they have to be effective readers who can read and dig out information from different materials at ease and achieve their overall academic endeavor. For this purpose, I tried to guide them how they can read and understand different kinds of literary texts. Counseling is also important here. So, I tried to counsel them towards the importance of reading so that students have to practice and deal with reading comprehension tasks."

This shows that lack of emphasis give to literary text to teach reading skills is one of the determinant factors the practice of teacher in teaching reading through literary texts.

This factor includes the supply of different classroom supervision and parents' relation. School supervisors should observe how the teaching and learning activities were carried out because they might give solutions about the problems like that of classroom management, the large class size and to check weather an appropriate teaching methods were applied in the classroom or not. In addition to this schools should communicate with students' parents because parents should support the students with texts and other reading materials. In addition to this 
parents should encourage the students as they read texts and other materials at home. All of these activities are important to improve students reading ability. For instance, teacher 5 said, "reading passages in the classroom is not enough to improve the students reading ability, in addition to this parents should encourage the students at home in order to improve their reading ability and also they should provide them the necessary reading materials."

In general, all the above factors that the teachers stated affected the teachers not to teach reading through literary text and paved the way to develop anxiety and hatred against the reading lesson which is the base for the students reading ability.

\subsection{Discussions of Results}

As it has already been indicated in chapter one, the main objective of this study was to assessing the challenges encounter on the teachers' practice of using literary texts to teach reading skills. In order to attain the intended objectives, the discussions and interpretations of the analyzed data obtained through the two data gathering instruments based on the research questions stated below.

\subsubsection{Challenges that Affect the Practices of using literary text in teaching reading}

The objective of this is to identify the factors which hinder the teachers not to use literary texts in reading class (if any). In order to achieve this objective the research designed a search question: What are the factors which hinder the teachers not to use literary texts in reading class (if any)?. So, five factors related to students, teachers, subject content, context, and school related were used to assess the extent these factors affected teachers not to use literary texts in reading class. The results obtained from the instruments are discussed as follows.

One of the factors considered was students' related factors. The results obtained from teachers showed that factors related to students are highly influence to teacher not to use literary text in reading class this students' poor background knowledge, low motivation or interest to learn reading literary texts. This is also sported by open ended questions.

Similarly, the result from focused group discussion also indicated that students have a big problem: they were not well prepared, motivated, and willing to attend their class actively. All the participants reported that students faced difficulties because of lack of the knowledge of vocabulary and grammar, low background knowledge of the subject and their negative attitude towards reading skills through literary text are the factor which are related to students.

Regarding this factor, text comprehension requires both language knowledge (vocabulary and grammar knowledge) and recognition of key ideas (Grabe, 2004). Supporting this result, John (2005) explained that students who lack adequate vocabulary have difficulty of getting meaning from what they read, so they read less because they find reading difficult. Similar to this the current study also founds the students poor background and linguistic knowledge, low attitude towards reading comprehension and inadequate knowledge of the language affect the practice of teachers in teaching reading comprehension. In the support of this study result, Bedasa (2013) indicates that cultural and content/ topic unfamiliarity, limited vocabulary knowledge the problems impede the teachers to implement teach reading comprehension.

Thus, the students were negatively affecting the practice of the teachers' not use literary text in pof teaching reading.

Another factor which hinders the practice of teachers is factors which are sourced from teachers. The results obtained from questionnaire in relation to teachers indicated teachers This shows that teachers related factors have low influences in teaching reading through literary effectively. Probably it is possible to say teachers considered themselves as they were not factors to influence in teaching reading comprehension whereas students responded the reverse. Moreover, even though the teachers' were not considered themselves a factor for teaching reading comprehension the students' responded that the teachers' were not engage in all reading phases and they did not teach different reading strategies in their reading class.

Similar to this the result focus group discussion also indicates that teachers were not considered themselves they are not a factor for their proper teaching of reading comprehension. In addition to this, although most of the teachers did not express clear awareness of reading strategies, they thought that reading instruction should involve strategy training. In the filed note the result there is teachers were lecture oriented rather than using newly developed strategies and apply multiple strategies while students were passive listeners except very few participants. So, this; indicates that the teachers' method which employee in the classroom was not proper.

Similar to this result obtained from the current study, Tasneem(2016) explained that 'Teachers perceived English learning is challenging for the language learners in the present context. In this case the socio-economic factors, educational factors and learners psychological factors may likely contribute to learners' low performance in the language classrooms"(p.187). There is often reluctance by teachers, course designers and examiners to introduce unabridged and authentic texts to the EFL syllabus. This can be due that there is a general perception that literature is particularly complex and inaccessible for the foreign language learner and can even be detrimental to the process of language learning (Ur, 1996).

Although some teachers claim that they do such activities. In connection to this Dennis (2008), stated that the 
type of instruction that a student receives will also affect reading comprehension and strategies for improving reading comprehension must be taught directly by teachers. Due to this fact, EFL teachers need to be selective and analytical to choose suitable methodology which helps them to implement in their actual classroom.

Supporting this finding, McDonough and Shaw (1993), and Stern (1983) list teachers' factors that affect students' language learning. These include: attitude toward teaching the skills, beliefs about language teaching, and language teaching experiences, knowledge of subject matters, and language teaching methods. As the result obtained from teachers' questionnaire of this finding indicates that the teachers were not consider the factor for their practice but the students result was supported the scholars view.

Subject contents are also considered one of the factors. The result obtained from questionnaire responded as factors related to subject content moderately influence teaching reading comprehension. Moreover, in result obtained from open ended questions revealed that the content of the text book was not designed effectively by considering students cultural, and linguistic background, there is a repetition of the content that makes the students bored, and since the content was too long it push the teachers to select the content and ignore some of the strategies.

Focus group discussion result indicated that the text book has many pages to cover all the contents on time as a result they obliged to be fast rather than teaching each of the contents. And it also indicates that the contents of the text book were not designed by including different literary text in reading lesson. The teachers reported that the reading material should be interesting or at least related to the background knowledge of the students.

In relation to the text book content related factors, the result of the current study that is consistent with the finding of Salatac and Akyel (2002) found out that the texts should be based on learners' interest and background knowledge. Concerning the extent of influence of textual factors in reading comprehension Asfaw (2008) found that lack knowhow of comprehension as the ability to comprehend academic texts impede at high extent, and textual difficulty hinders reading comprehension of students at high extent. How of poor foreign language competency and didn't differentiate its impact on textual difficulty and their relationship.

Dennis (2008) also explained that a text book that is well organized and clear is called "considerate text" and text that is poorly organized and difficult to understand can be called "inconsiderate text." The more inconsiderate the text, the more work will be required of a reader to comprehend the text. And the complexity of the texts is one of the factor is influenced by the readers' strength and fluency in language and their comprehending of its applications and different meanings. But, the result obtained from focus group discussion and questionnaire indicates that the text book was not designed by literary texts.

Another factor considered as a factor affecting teacher not to use literary text in reading class was context related factors. Teachers questionnaire indicates that as factors related to contexts are highly influence teaching reading comprehension. In the support of this result the result obtained from the open ended questions illustrates shortage of time to handle multiple reading strategies and engage the all the students in their reading class.

Focus group discussion result that the classroom context highly affects students learning as well as teachers teaching practice. Numbers of students in a classroom, time allocated for a lesson, cultural backgrounds where students grew up were some of the context related factors affecting the teaching and learning in English class reading comprehension in particular. In the classroom observation-field notes result ensured that the sitting arrangement, the class size was daunting factors exist in every classrooms and the time which was given for the reading lesson is not enough and impedes the teachers don not teach all reading phases and related strategies properly.

In collaboration to the findings of the current study the work of Akinbade (2007), who found that a conducive environment is the bedrock without which learning would be impaired and not effective. Similarly, the result of the current study also indicates that the school arrangement, class size and the time give to accomplish the reading tasks.

The last but not the least factor considered as a factor affecting teacher not to use literary text in reading class was school related factors. Teachers questionnaire indicates that as factors related to schools are highly influence teaching reading through literary texts. In the support of this result the result obtained from the open ended questions illustrates shortage of adequate training to handle multiple reading strategies and engage the all the students in their reading class. Similar to this Solomon (2013) found that problems related to school administration like school supervision, supply of text book, large class size affect the practice of teachers in teaching reading and students reading ability.

\section{SUMMARY, CONCLUSIONS AND RECOMMENDATIONS}

In this part of this paper three important parts: summary, conclusions and recommendations are presented which helps to complete it. In the summary part major findings are included whereas the lessons learned throughout the study are concluded and presented under the conclusions. Finally, based on the summary and conclusions possible recommendations are reported. 


\subsection{Summary}

The main objective of this study was to Assessing the Challenges Encounter on the Teachers' Practice of Using Literary Texts to Teach Reading Skills: Some Selected High Schools in Enbse Sar Mider Woreda. To this end, the following leading questions were designed.

1. What are the challenges that the teachers encounter when they teaching reading through literary texts?

2. What are the dominant factors which hinders the teachers that the teachers encounter when they teaching reading through literary texts (among the identified factors)?

To answer these research questions data were collected from teachers using questionnaires, and interview. The questionnaires were administered to all 38 English language teachers in the three schools. All teachers returned the questionnaires; and interview was conducted with six teachers who were teaching in grade $9^{\text {th }}$ students. The quantitative were analyzed in descriptive statistics (percentages and frequency) and the qualitative one is through nation. Based on the analysis of the data, the following findings were obtained.

The analyses of the data which obtained from questionnaire and interview indicates that Grade 9 English language teachers in the study school have faced various challenges in delivering their reading lesson effectively. Of which, unstructured and unorganized literary reading texts, content authenticity, difficulty, and length of reading texts that did not suit and motivate teachers and students interest are the major ones.. Besides, as presented all of the teachers also confirmed that literary texts like poem, short stories, extracted novels, diaries; biographies of a famous person are not authentic in addressing their cultural, political and social elements. Therefore, so as to meet the needs and interest of the teachers' and students', English language curriculum, syllabus designers should also be careful in considering the students cultural background, and linguistic level, so that teachers and students keep interested in teaching and learning reading in a more rewarding and real life situations. The result obtained from interview also indicates that the teacher were not teach reading skills by using literary text due to lack of motivation, lack of experience, poor language ability, shortage of time, students interest, difficulty of the text and low pedagogical skills of using literary texts are the dominant factors.

\subsection{Conclusions}

Based on the results obtained and the summary stated above, the following conclusions are drawn.

1. Above all, we infer that EFL teachers' implementation and effectiveness of teaching reading skill through literary texts have been challenged by various factors. Among those that minimize their effectiveness are: teachers' negative perception, lack of experience in teaching literary texts and lack of preparation, content authenticity, difficulty, length, and students' motivation, and perception, large class size, shortage of time, lack of in-service training, lack of school supervision, unstructured and unorganized literary reading texts, content authenticity, difficulty, and length of reading texts that did not suit and motivate teachers and students interest are the major ones. Besides, as presented all of the teachers also confirmed that literary texts are not authentic in addressing their cultural, political and social elements, the syllabus of the text book, poor language ability, shortage of time, students' interest, difficulty of the text and low pedagogical skills of using literary texts are the identified factors.

2. Among the identified factors the result of this study indicates that student related problem ( language problem, lack of motivation, unfamiliar with literary texts, unable to understand every word in the text, lack of sufficient background knowledge, related to teachers (lack of motivation in teaching reading through literary text, lack of teaching experiences in teaching reading through literary text, and lack of exposure in reading literary texts, and their poor practice), related to subject matter (content authenticity, difficulty, length, and variety), related to context (class size, time and classroom arrangement), and final school related problem (lack of tearing and supervision) are the dominant factor.

\subsection{Recommendations}

Based on the results obtained, summary and conclusions made the researcher would like to recommend the following.

1. EFL teachers should give special attention for using literary texts in language classroom in the actual implantations so as to cater of their students' interest and make it more enjoyable, and also to develop the literacy capacity of students in general.

2. Teachers and parents should work together to arouse interests of students in reading especially on the importance of reading literary text in school and out of school.

3. To minimize the problem the ministry of Education and other concerned bodies should organize practice based trainings related with how to present reading lesson based on the application of the new course book with regarded to literary text.

4. Teachers of this grade levels should show the way how to read, understand, and use literary texts to teach reading and schools should work towards this goal.

5. The school administration should minimize the constraints that teachers face while they implement using literary text in language classroom, especially, by providing an equipment or materials (literary text, films, 
etc) which are expensive for teachers to get them easily and also the administration should offer a short time training about methods of English language instruction.

6. Moreover, further research should be conducted to find out the solution for the identified factors.

\section{References}

Alene Ketema. (2012). Investigation of EFL Teachers' and Students' Views Towards Using Literary Texts in EFL Classrooms: The Case of Aboker Preparatory School, Grade 12, Harari Region $\quad$ (M.A. Thesis). Haramaya: Haramaya University.

Kothari, C.R. (2004). Research Methodology: Methods and Techniques( $2^{\text {nd }}$ ed.). New Delhi, New Age Publishers. Grabe, W. (2004). Research on Teaching Reading. Annual review of applied linguistics, 24, 44,69.

Hall, G. (2005). Literature in Language Education. London: Macmillan

Lazar, G. (1993). Literature and Language Teaching: guide for teachers and trainers. Cambridge.

McNamara, C. (1999). General Guidelines for Conducting Interviews, Authenticity Consulting, LLC, Retrieved from www.managementhelp.org/evaluatn/intrview.htm

McNamara, C. (1999). General Guidelines for Conducting Interviews. From: http://www.mapnp.org/library/evaluatn/intrvi ew.htm.

Nuttall, C. (1982). Teaching Reading Skills in a Foreign Language. London: Heinemann Educational.

Nuttall, C. (1996). Teaching Reading Skills in a Foreign Language. Oxford: Reed Educational and Professional Publishing Limited.

McDonough and Shaw, C. (2003).Materials and Methods.A Teacher's Guide. (2 ${ }^{\text {nd }}$ ed.). $\quad$ Australia. Blackwell publishing.

Akinbade, A. (2007) Free education: Why we outsmart other states in Nigeria. The Nigerian Education Times 14 (May- June): 18.

Salataci, R. \& Akyel, A. (2002). Possible effects of strategy instruction on L1 and L2 reading. Reading in a foreign

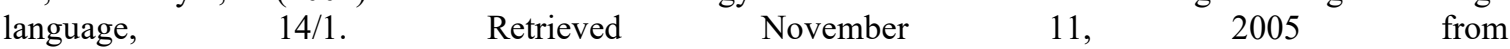
http://nflrc.hawaii.edu/rfl/April2002/salataci/salataci.html

Nuttall, C. (2005). Teaching Reading Skills in a Foreign Language. Oxford: Macmillan Education.

Özkan,A. \& A. Nejat T.A.(2014). Use of Literature in Reading Comprehension Classes by ELT Teachers.International journal of social sciences. Vol , 25 no. 1

Rido, A., Ibrahim, N. \&Nambiar, R.M.K., 2014, 'Investigating EFL Master Teachers' Classroom Interact on Strategies: A case study in Indonesian Secondary Vocational School', Procardia-Social and Behavioral Sciences 118, 420-424.Retrived from Https://Doi.Org/10.1016/J.Sbspro.2014.02.057

Tasneem, A. (2016). The role of literary texts in Pakistani EFL Classrooms: Issues and Challenges. Pakistan: University of Essex.

Wallace, C., (1992).Language Teaching: A Scheme for Educational Reading. Oxford: Oxford University press.

Yitagesu, Belete. (2017). Investigating the Role of Literary Texts in Developing Students' Reading Comprehension with Specific Reference to Grade Nine Students of Bole Community Secondary School. Addis Ababa: Addis Ababa University.

Dennis, D. V. (2008). Are Assessment Data Really Driving Middle School Reading Instruction? What we can learn from one student's experience. Journal of Adolescent and Adult Literacy, 51, 578-587. http://dx.doi.org/10.1598/JAAL.51.7.5

John, S. 2005. Effective Vocabulary Instruction. Insights on learning disabilities. 2(1): 1-10

Bedasa Melese. ( 2013). Assessing the Practices of Pre-reading Activities in EFL Classrooms: the Case of Gudeyajare Secondary School in East Wollega Zone, Oromia (Unpublished MA. Thesis). Haramaya University. 